\title{
Optimisation of Protein Extraction Methods for Metaproteomics of Freshwater Microbial Communities
}

\author{
D. A. Russo, J. Pandhal \\ Department of Chemical and Biological Engineering, Faculty of Engineering, University of Sheffield.
}

\begin{abstract}
Recent developments in the molecular biology toolbox allow access to the genetic structure and diversity of microbial communities. More specifically, the advances in metaproteomics allow us to identify the functional expression of the genome and link this information to the biogeochemical processes of an ecosystem. One of the challenges, in this field, is the optimisation of protein extraction methods from environmental samples where protein concentrations can be low and the presence of interfering substances high. Experiments were conducted by extracting proteins from freshwater microbial communities utilising an array of physical and chemical methods. We used protein yield and 1D SDS-PAGE resolution as deciding factors. Liquid $\mathrm{N}^{2}$ grinding and freeze-thaw cycles resulted in, after purification, an enhanced resolution and protein yield. Furthermore, regarding sample purification, the use of detergent removal columns resulted in higher yields but literature indicates that acetone precipitation is more efficient in removing interfering substances.
\end{abstract}

Keywords Ecological Function; Environmental Samples; Metaproteomics; Microbial Community; Protein Purification

\section{INTRODUCTION}

Currently there is limited knowledge on how microbial diversity relates to biogeochemical processes on a whole ecosystem level. This knowledge can be obtained through metaproteomics. Proteins are central to the functioning of cells and therefore a description of the proteome can provide information on the metabolic function of cells in a specific state [1]. Similarly metaproteomics can provide understanding of the catalytic potential of an ecosystem. The success of metaproteomic techniques relies on the ability to extract and purify proteins from complex environmental samples. Ideally, the chosen technique would allow the recovery of protein sufficiently pure for downstream analysis (e.g. tandem mass spectrometry) and, simultaneously, that is representative of the pool of organisms from where it was extracted. However, the biological complexity of the environmental metaproteome and the existence of interfering compounds such as humic and phenolic compounds render protein resolution and characterisation difficult [2]. The objectives of this study were to find a robust and repeatable method that would benefit protein yield, protein resolution and downstream processing and to address the gaps in knowledge regarding protein extraction from freshwater microbial communities.

\section{MATERIALS AND METHODS}

\subsection{FIRST RUN}

$5 \mathrm{~L}$ were collected from LG pond, pre filtered, with blotting paper, and submitted to TFF to reduce volume to $1 \mathrm{~L}$. These samples were then centrifuged (10000g for $10 \mathrm{~min}$.) to recover the cells and each of the fractions was washed, three times, with a different washing buffer (TEAB, $50 \mathrm{mM}$ Tris $\mathrm{HCL}$ (pH 7.4), $10 \mathrm{mM}$ Tris - HCL + $0.1 \mathrm{mM} \mathrm{EDTA}+5 \mathrm{mM} \mathrm{MgCl}_{2}$ ). These buffers were chosen due to their compatibility with all downstream processing (i.e. mass spectrometry) and their wide use in the literature [2, 3] Each washed fraction was submitted to four different lysis treatments. All protein yields were quantified with Bradford Ultra (Expedeon, UK). Boiling method: The sample was re-suspended in $500 \mu \mathrm{L}$ of
$\mathrm{H}_{2} \mathrm{O}$ and $500 \mu \mathrm{l}$ of sample buffer. It was then boiled in a water bath for 10 minutes. Chemical method: The sample was resuspended in $1 \mathrm{~mL}$ of Guanidine-HCL, $10 \mathrm{mM} \mathrm{DTT}, 50 \mathrm{mM}$ Tris and $10 \mathrm{mM} \mathrm{CaCl}_{2}$, at $\mathrm{pH} \mathrm{7.6}$, and incubated overnight at $37^{\circ} \mathrm{C}$. Sonication method: The sample was re-suspended in 8 M Urea, $2 \mathrm{M}$ Thiourea, 4\% CHAPS, $30 \mathrm{mM}$ Tris and $1 \mathrm{mM}$ DTT. It was then sonicated (Branson Sonifier 450), on ice, at power setting 3 and duty cycle of $30 \%$ for 5 cycles of 40 seconds. Freeze-thaw method: The sample was resuspended in $50 \mathrm{mM}$ Tris-HCL, $10 \%$ sucrose, $1 \mathrm{mM}$ DTT, 600 $\mu \mathrm{g} / \mathrm{mL}$ and $2 \mathrm{mM}$ EDTA. The sample was submitted to 4 freeze thaw cycles between liquid nitrogen and a $60^{\circ} \mathrm{C}$ water bath.

\subsection{SECOND RUN}

In the second run of protein extraction all samples were resuspended in TEAB $100 \mathrm{mM}$ and $0.1 \%$ SDS (w/v) and submitted to two different lysis methods (liquid $\mathrm{N}_{2}$ grinding and freeze thaw) followed by two different purification methods (acetone precipitation and HiPPR detergent removal spin columns (Thermo Scientific, USA).

\section{RESULTS}

3.1. PROTEIN YIELD

\subsubsection{FIRST RUN}

Table 1. Protein yields, and gel lane number in brackets, of the first run.

\begin{tabular}{|c|c|c|c|c|}
\hline $\begin{array}{c}\text { Protein } \\
(\mathbf{m g} / \mathbf{m L})\end{array}$ & Boiling & Chemical & $\begin{array}{c}\text { Freeze- } \\
\text { thaw }\end{array}$ & Sonication \\
\hline TEAB & $\begin{array}{c}0.121 \\
(1)\end{array}$ & $0.299(3)$ & $0.957(5)$ & $0.205(7)$ \\
\hline $\begin{array}{c}50 \mathrm{mM} \text { Tris- } \\
\text { HCL }\end{array}$ & $\begin{array}{c}0.104 \\
(9)\end{array}$ & $\begin{array}{c}0.070 \\
(11)\end{array}$ & $\begin{array}{c}0.699 \\
(13)\end{array}$ & $0.166(15)$ \\
\hline $\begin{array}{c}10 \mathrm{mM} \text { Tris- } \\
\mathrm{HCL}\end{array}$ & $\begin{array}{c}0.220 \\
(17)\end{array}$ & $\begin{array}{c}0.079 \\
(19)\end{array}$ & $\begin{array}{c}1.638 \\
(21)\end{array}$ & $0.111(23)$ \\
\hline
\end{tabular}


3.1.2. SECOND RUN

Table 2. Protein yields, and gel lane number on the left, of the second run.

\begin{tabular}{|c|c|c|}
\hline Sample & Treatment & $\begin{array}{c}\text { Protein } \\
(\mathrm{mg} / \mathrm{mL})\end{array}$ \\
\hline 1 & $\begin{array}{c}\text { Freeze-thaw + Acetone } \\
\text { precipitation }\end{array}$ & 0.148 \\
\hline 2 & $\begin{array}{c}\text { Freeze-thaw + Detergent } \\
\text { removal columns }\end{array}$ & 0.577 \\
\hline 3 & Grinding + Acetone precipitation & 0.129 \\
\hline 4 & $\begin{array}{c}\text { Grinding + Detergent removal } \\
\text { columns }\end{array}$ & 0.684 \\
\hline
\end{tabular}

3.2. Protein Resolution (1D SDS-PAGE)

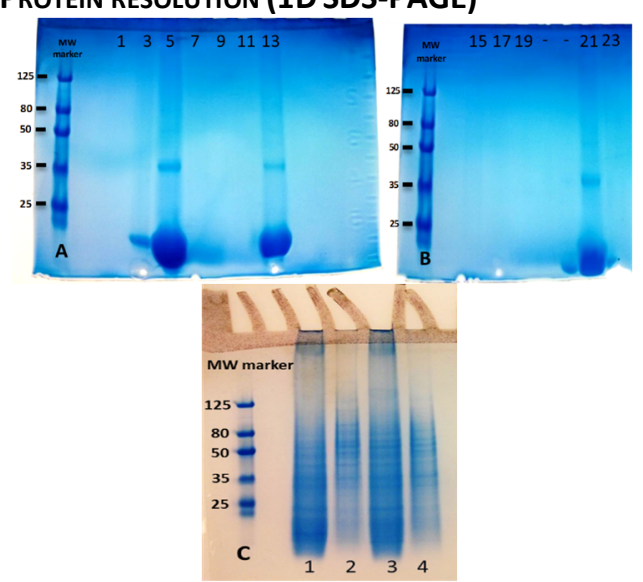

Figure 1. SDS-PAGE (12\%), with coomassie brilliant blue stain, loaded with samples from the first (a, b) and (c) Second run.

\section{Discussion}

The protein yields of the first run (Table 1) showed that the highest yield was obtained through the freeze-thaw method. The other three method yielded similar low levels of protein concentration. Regarding wash buffers, there seems to be no difference in protein yield or resolution, therefore variation of wash buffer is expected to not produce any visible difference. The gel lanes with protein samples obtained through the freeze thaw method (lanes 5 and 13 in Fig. 1(a) and 21 in Fig. 1(b) were the most visible but show very poor resolution. The other lanes, although loaded with the same amount of protein, fail to produce any visible bands, which could be due to incomplete cell lysis. The first run lacked a purification step and this could be the explanation for the poor gel resolution. In the second run (Table 2) the best method of the first run (freeze-thaw) was compared with a published method that proved efficient for algal cells (liquid $\mathrm{N}_{2}$ grinding) [4]. Furthermore, two purification methods (acetone precipitation and detergent removal columns) were also tested with both lysis methods. In comparison to the first run, immediate differences in gel resolution were seen (lanes 1-4 in Fig. 1(c)). Protein yield was similar between methods and differed mainly between purification methods. Both samples that underwent the precipitation step showed yields $75-80 \%$ lower than their non-precipitated counterparts. Regarding gel resolution, the precipitated samples (lanes 2 and 4 in Fig. 1(c)) showed much higher background noise whereas the nonprecipitated samples (lanes 1 and 3 in Fig. 1(c)) are clearer and more defined. Initial evidence indicates that column purification is a better method for yield and resolution. However, a precipitation step allows the option for a buffer exchange and can, potentially, remove other interfering substances that effect downstream processing.

\section{CONCLUSION}

The protein extraction method developed in this study allows for reproducibility, robustness and flexibility regarding the purity/quantity trade-off. The combination of stronger physical methods with a milder extraction buffer resulted in an improved gel resolution and easier sample handling. Efforts are being made to test this optimised method with different environmental samples containing variable biomass feedstock and compare mass spectrometry coverage of the different extraction methods. The continuous improvement of the proteomic workflow should increase our ability to probe microbial community dynamics in complex environments.

\section{ACKNOWLEDGMENTS}

This work was supported by Natural Environment Research Council and Technology Strategy Board for provision of funding through a Research Fellowship (NE/J024767/1). We are thankful to Heather Callahan at Cambio for useful discussions and Narciso Couto for his technical expertise.

\section{REFERENCES}

1. Hettich R, Sharma R, Chourey K, Giannone R. Microbial Metaproteomics: Identifying the Repertoire of Proteins that Microorganisms Use to Compete and Cooperate in Complex Environmental Communities. Current Opinion in Microbiology. 2012; 3(15): p. 373-80.

2. Pierre-Alain $M$, Christophe $M$, Séverine $S$, Houria A, Philippe $L$, Lionel R. Protein Extraction and Fingerprinting Optimization of Bacterial Communities in Natural Environment. Microbial Ecology. 2007; 53: p. 426-434.

3. Ogunseitan OA. Direct Extraction of Protein from Environmental Samples. Journal of Microbiologial Methods. 1993; 17: p. 273-281.

4. Longworth J, Noirel J, Pandhal J, Wright P, Vaidyanathan S. HILIC- and SCX-Based Quantitative Proteomics of Chlamydomonas Reinhardtii during Nitrogen Starvation Induced Lipid and Carbohydrate Accumulation. Journal of Proteome Research. 2012; 11: p. 5959-5971. 